Original article

\title{
Knowledge and judgments about standard precautions for nosocomial infection: comparative analysis of medical vs. non-medical students
}

\author{
Elmira Kultanova ${ }^{1}$, Milton Severo ${ }^{2}$, Anar Turmukhambetova ${ }^{1}$ \\ ${ }^{1}$ Karaganda Medical University, Karaganda, Kazakhstan \\ 2 University of Porto, Porto, Portugal
}

Received 22 January 2021, Revised 7 April 2021, Accepted 16 July 2021

(C) 2021, Russian Open Medical Journal

\begin{abstract}
Background - Nosocomial infection (NI) is among the most common and serious challenges in a healthcare system. Health workers and medical students play an important role in prevention of NI. Despite advances in the field of medicine in Kazakhstan, low detection rate of NIs remains unchanged, which could be due to a lack of awareness of the standard precautions for infection control among medical students and health workers. This study is aimed at examining knowledge and judgments on NIs among medical and nonmedical students.

Material and Methods - We conducted a cross-sectional paper-based survey to examine the knowledge and judgments about the standard precautions for $\mathrm{NI}$ among medical and non-medical students. Data collection took place between September 21 and December 20, 2017.

Results - The study enrolled 2,817 students. The mean overall score $( \pm S D)$ was $2.045 \pm 1.29$. Medical students had a better mean overall score (2.113) than non-medical students $(1.785 ; \mathrm{p}<0.001)$. Awareness of the standard preventive measures was increasing with a year of study, but still just one-third of year 5 medical students were aware of standard prevention (36.3\% vs. $17.4 \%$ for non-medical students; $\mathrm{p}<0.001$ ).

Conclusion - The overall score of our survey indicated inadequate knowledge and awareness of the guidelines on infection prevention and control among both medical and non-medical students. In order to improve patient safety and welfare, the courses on infection control should be introduced into the curricular of medical universities in Kazakhstan.
\end{abstract}

Keywords: nosocomial infection, standard precautions, knowledge, students.

Cite as Kultanova E, Severo M, Turmukhambetova A. Knowledge and judgments about standard precautions for nosocomial infection: comparative analysis of medical vs. non-medical students. Russian Open Medical Journal 2021; 10: e0302.

Correspondence to Elmira Kultanova. Address: Karaganda Medical University, 40 Gogol St., Karaganda 100008, Kazakhstan. E-mail: elmirakultanova@mail.ru.

\section{Introduction}

Nosocomial infections (NI) are among the most relevant public health problems worldwide, contributing to the increase in morbidity, mortality, and cost of diagnosing and treatment. They lead to reduction in quality of life in the population [1-3]. The incidence rates of $\mathrm{NI}$ are the best indicator of the quality of medical services: high incidence of $\mathrm{NI}$ morbidity indicates low quality of medical services. Prevalence of $\mathrm{NI}$ in developing countries is 2-3 times higher than in Europe or United States. According to the World Health Organization, $5-10 \%$ of all hospitalizations results in $\mathrm{NI}$ in North America and Europe, while Latin America, sub-Saharan Africa and Asia show over $40 \%$ of hospitalizations with $\mathrm{NI}$ [4]. Annually, 5 million $\mathrm{NI}$ cases were registered in Europe leading to 50,000-135,000 of additional deaths and the damage to the healthcare system in the amount of 12-24 billion euros [5].

Compliance with standard precautions would prevent global outbreaks and damage from NI. According to standard methods' precautions, blood, body fluids, secretions, excretions (except sweat), non-intact skin, and mucous membranes may contain transmissible infectious agents $[6,7]$. Adequate hand hygiene, along with the use of appropriate personal protective equipment and aseptic agents are key remedies in the prevention of $\mathrm{NI}[6]$.

Healthcare workers are the basic party for preventing $\mathrm{NI}$ when applying infection control practices. In fact, healthcare workers, including nurses and medical students, can directly reduce NI rate by means of recognizing and following the standard precaution procedures $[8,9]$. Numerous studies highlighted a significant role of education and judgments of medical students in preventing $\mathrm{NI}$ [10-18]. Knowledge of infection control and compliance of medical students with $\mathrm{NI}$ prevention procedures varied across countries and training programs. Several studies, involving nursing students, indicated lack of knowledge of, and compliance with, infection control procedures. For instance, nursing students in Jordan exhibited poor knowledge of standard precautions (7.82 of 18) and compliance with them (49.36 of 85) [19]. Adequate monitoring of students' performance in terms of following the standard precautions did not reveal sufficient knowledge among medical students [20]. Furthermore, medical students at universities of 
Karachi (Pakistan) have also demonstrated weak knowledge and practices of infection control, e.g., regarding the method of surgical scrubbing [21]. Medical students of Saudi Arabia exhibited acceptable knowledge, which could depend on the primary information source. Despite that, Abdullah Khubrani et al. pointed out that a curriculum should be amended to increase an emphasis on the infection control [22]. Undergraduate nursing students demonstrated decent level of knowledge. Despite this, most of them had poor attitude and incompetent practice concerning infection control procedures. Although students demonstrated a good attitude towards basic hand hygiene rules, less than a half of the students uses personal protective equipment. However, it is important to point out the necessity to improve knowledge concerning the standard precautions of NIs [23].

Most studies were dedicated to evaluating knowledge and attitude towards $\mathrm{NI}$ among medical students. Their poor knowledge could be associated with a lack of awareness of standard precautions for infection control at medical universities and inadequate programs of medical education. However, no one attempted to conduct a comparative assessment of students' knowledge, regardless of their training program. The content and quality of medical training programs should promote better knowledge and awareness. Each correct answer was assigned 1 point, while each incorrect answer was scored as 0 points. Each medical student in presumed to accomplish high academic results in infection control, whereas non-medical students are not required to adhere to the guidelines since they cannot play any role in the emergence of NI. Accordingly, the goal of our study was to examine and compare knowledge and judgments on NIs among medical versus non-medical students.

\section{Material and Methods}

\section{Subjects and sampling}

We conducted a cross-sectional paper-based survey among undergraduate students based on the so-called two-gate design [24]. The study involved two different population (gates): medical students (School of Medicine, Karaganda Medical University) and non-medical students (School of Economics, Karaganda State University). Economics students were selected to represent nonmedical students. Their curriculum did not include any medical courses, specifically those related to infection control. significance level of 0.05 we would need 582 students from each school. We decided that the participation rate could be roughly $70 \%$. Consequently, we needed to include all economics students $70 \%$ of the School of Medicine students. Data collection took place between September 21 - December 20, 2017.

\section{Questionnaire design}

The questionnaire (Appendix 1) was adapted from $\mathrm{H}$. Sax et al., 2005 [13] and Tavolacci et al., 2008 [14]. The 16-item questionnaire had three sections: respondents' characteristics (four questions), knowledge of transmission precautions (six questions), and judgments about the precautions (six questions). The respondents' characteristics included age, gender, field of study, and year of study. The section related to knowledge about transmission precautions included six multiple choice questions related to the knowledge on the prevention concept sensu CDC guidelines [19-20]. In the third section, the questions were aimed
Considering a power of 0.95 and effect size of $20 \%$ and

at determining respondents' judgements on prevention standards, risks of $\mathrm{NI}$, the epidemiological situation with $\mathrm{NI}$ in Kazakhstan (prevalence, mortality, extended hospitalization), and the most common reasons for non-compliance with the guidelines. A group of professors from Karaganda Medical University independently evaluated the correctness of the answers.

\section{Statistical analysis}

Each correct and incorrect answer was assigned 1 point and 0 points, respectively (the maximum score was 6 points). Two models were applied to the data to evaluate the its dimensionality. The first model represented one-factor latent trait analysis (LTA) and the second model was two-factor LTA [21]. LTA assumes that the probability of correctly answering an item by an individual is explained by one (one-factor model) or more (two-factor model) continuous variables, commonly called latent variables. LTA is form of factor analysis for dichotomous variables, that considers an existence of one or more underlying factors.

The standardized factor loadings of the model are usually used to interpret the results. Each of these expresses the correlation coefficient between the latent variable and an underlying continuous variable obtained from each item. An association is classified as weak if the corresponding standardized loading is under 0.30 , moderate if it is between 0.30 and 0.70 , and strong if it exceeds 0.70 .

The Bayesian information criterion (BIC) was used to compare the goodness of fit between the two models. Pairwise two-way margins' residuals and the item fit statistics were used to confirm the goodness of fit.

Cronbach's alpha was used to assess the internal consistency of items, and indirectly evaluated the reliability of the scale.

The Spearman-Brown prediction formula was employed to estimate the hypothetical number of items needed to obtain Cronbach's alpha of 0.7.

Analysis of variance (ANOVA) was used to compare the means of knowledge score among genders, fields of study and years of study. The analysis of covariance (ANCOVA) was used to estimate the knowledge score means adjusted by gender, field of study and year of study.

Table 1. Percentage of correct answers on the knowledge of nosocomial infections vs. field of study

Incorrect answers N (\%) Correct answers N (\%) $p$

The most important vehicle of transmitting infectious agents in the hospital

\begin{tabular}{|c|c|c|c|}
\hline $\begin{array}{l}\text { Medical students } \\
\text { Non-medical students }\end{array}$ & $\begin{array}{c}1870(84.6) \\
526(86.7)\end{array}$ & $\begin{array}{l}340(15.4) \\
81(13.3)\end{array}$ & 0.212 \\
\hline \multicolumn{4}{|c|}{ The most effective means to reduce transmission of infectious agents } \\
\hline Medical students & $1395(63.1)$ & 815 (36.9) & \multirow{2}{*}{$<0.001$} \\
\hline Non-medical students & $440(72.5)$ & $167(27.5)$ & \\
\hline \multicolumn{4}{|c|}{ The main purpose for using non-sterile gloves } \\
\hline Medical students & $1507(68.2)$ & $703(31.8)$ & \multirow{2}{*}{0.391} \\
\hline Non-medical students & $425(70.0)$ & $182(30.0)$ & \\
\hline \multicolumn{4}{|c|}{ The main benefit of hand hygiene } \\
\hline Medical students & $1422(64.3)$ & $788(35.7)$ & \multirow{2}{*}{0.065} \\
\hline Non-medical students & $415(68.4)$ & $192(31.6)$ & \\
\hline \multicolumn{4}{|c|}{ The goal of preventing the transmission of infectious agents } \\
\hline Medical students & $738(33.4)$ & $1472(66.6)$ & \multirow{2}{*}{$<0.001$} \\
\hline Non-medical students & $338(55.7)$ & $269(43.3)$ & \\
\hline \multicolumn{4}{|c|}{ Recognition of the ubiquitous risk of the body fluids } \\
\hline Medical students & $1616(73.1)$ & $594(26.9)$ & \multirow{2}{*}{0.617} \\
\hline Non-medical students & $450(74.1)$ & $157(25.9)$ & \\
\hline
\end{tabular}




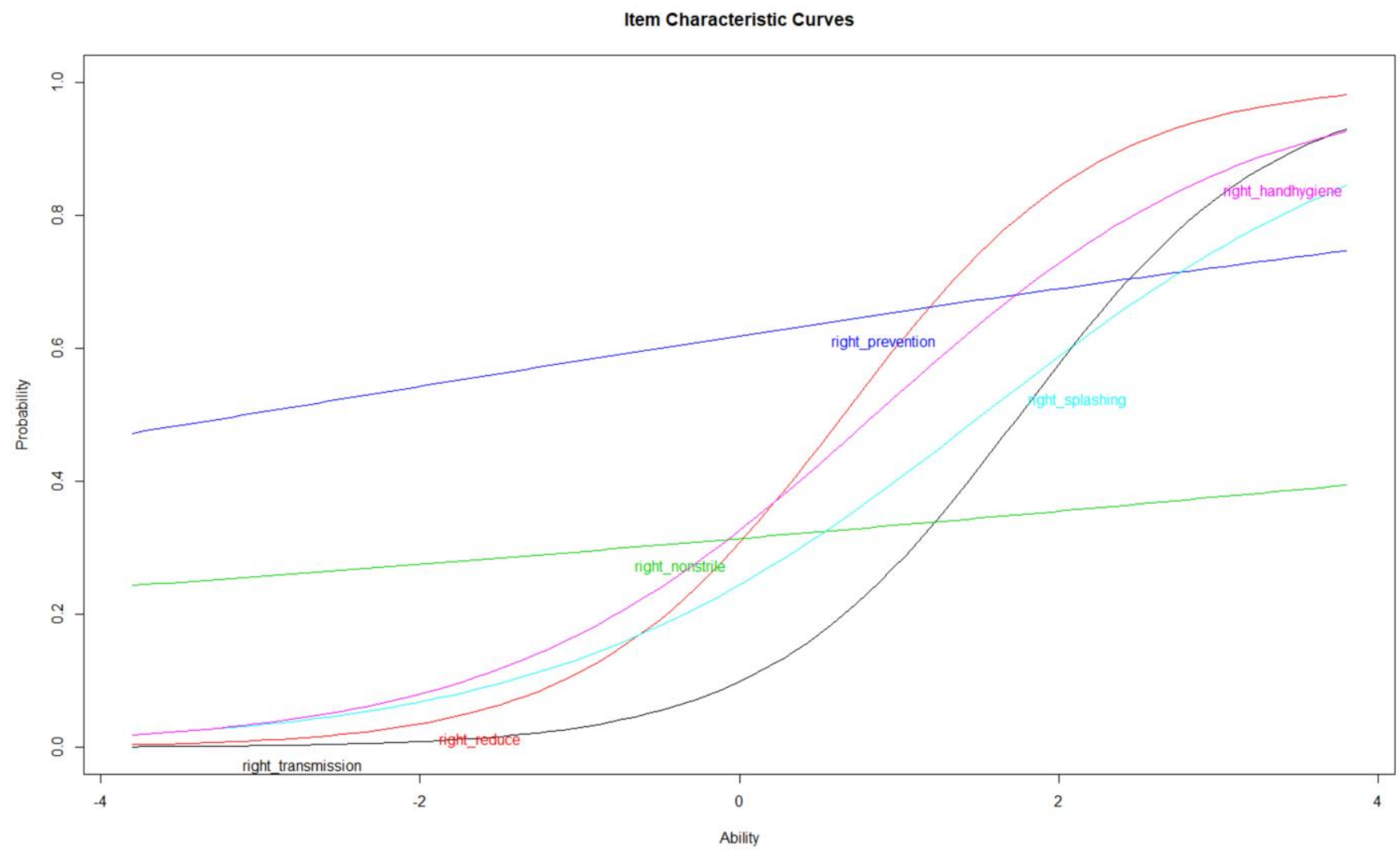

Figure 1. Item-characteristic curves for the single-parameter logistic model of the item response theory.

Table 2. Proportion of correct answers and standardized factor loading for each statement

\begin{tabular}{|c|c|c|c|}
\hline & Correct answers N (\%) & Factor Loadings & Cronbach's alpha if the item is removed \\
\hline The most important vehicle of transmitting infectious agents in the hospital & 421(14.9) & 0.8 & 0.3 \\
\hline The most effective means to reduce transmission of infectious agents & $982(34.5)$ & 0.8 & 0.2 \\
\hline The main purpose for using non-sterile gloves & $885(31.4)$ & 0.1 & 0.4 \\
\hline The main benefit of hand hygiene & $981(34.8)$ & 0.7 & 0.2 \\
\hline The goal of preventing the transmission of infectious agents & $1761(61.8)$ & 0.2 & 0.3 \\
\hline Recognition of the ubiquitous risk of the body fluids & $751(26.7)$ & 0.6 & 0.2 \\
\hline Cronbach's alpha & & & 0.3 \\
\hline
\end{tabular}

Chi-square tests were used to compare proportions of categorical variables. P-value $<0.05$ was considered a significance level.

Data analysis was performed using $\mathrm{R}$ Project for Statistical Computing and IBM SPSS Statistics version 25 (the citations: R Core Team (2017); R: A language and environment for statistical computing. R Foundation for Statistical Computing, Vienna, Austria. URL https://www.R-project.org/).

\section{Results}

A total of 2,817 questionnaires were included in this study, and $402(12.5 \%)$ students refused to participate in the survey and the questionnaires returned unfilled.

Age of participants ranged from $16-34$ years old with a mean (SD) of 20.04 (1.82); 78.5\% were medical students. The distribution of respondents at the training course was the following: year 1 students $-23.9 \%$, year $2-17.0 \%$, year $3-16.9 \%$, year $4-25.2 \%$, and year $5-16.9 \%$. Male/female ratio was 0.51 (the sex ratio was 0.46 for medical students and 0.55 for non-medical students).
Table 1 presents a percentage of correct answers to the questions on the knowledge of NI vs. the field of study. Medical students scored a higher number of correct answers only for two questions (on the effective means to reduce the risk of transmission of infectious agents and on prevention of infectious agent transmission) with a statistically significant difference between the fields of study of $<0.001$ in both questions. The remaining questions did not exhibit statistically significant differences among medical and non-medical students.

A one-factor LTA was fit to six items. Four items showed a moderate-to strong positive association, whereas two presented just a weak positive association (Table 2). Figure 1 demonstrates that the probability of correct answers for four items increases sharply (high factor loading), while it increases slowly for two other items (low factor loading).

In our study, Cronbach's alpha for two items was higher than the current alpha for the entire scale: 0.31 (Table 2). SpearmanBrown prediction formula suggested the necessity to increase to 30 items to have Cronbach's alpha of 0.7. 
Table 3. Unadjusted and adjusted means by gender, field of study and year of study

\begin{tabular}{lccc}
\hline & $\begin{array}{c}\text { Unadjusted mean } \\
(95 \% \mathrm{Cl})\end{array}$ & $p$ & $\begin{array}{c}\text { Adjusted mean } \\
(95 \% \mathrm{Cl})^{*}\end{array}$
\end{tabular}

* Adjusted for all variables in the table.

Table 4. Analysis of responses to perception and attitude questions

\begin{tabular}{|c|c|c|c|c|c|}
\hline & \multicolumn{4}{|c|}{ Responses } & \multirow[b]{2}{*}{$p$} \\
\hline & 1 & 2 & 3 & 4 & \\
\hline \multicolumn{6}{|c|}{ Concept of standard precautions (country specific) } \\
\hline & $\begin{array}{l}\text { Never heard } \\
\text { about it }\end{array}$ & $\begin{array}{l}\text { I heard } \\
\text { about it }\end{array}$ & $\begin{array}{c}\text { Vague } \\
\text { knowledge }\end{array}$ & I know it well & \\
\hline \multicolumn{6}{|l|}{ Field of study } \\
\hline Medical students & $6.3 \%$ & $27.5 \%$ & $40.1 \%$ & $26.2 \%$ & \multirow[t]{2}{*}{$<0.001$} \\
\hline Non-medical students & $16.1 \%$ & $25.2 \%$ & $47.6 \%$ & $11.0 \%$ & \\
\hline \multicolumn{6}{|l|}{ Gender } \\
\hline Male & $10.1 \%$ & $23.4 \%$ & $40.8 \%$ & $25.7 \%$ & \multirow[t]{2}{*}{0.001} \\
\hline Female & $7.6 \%$ & $28.7 \%$ & $42.1 \%$ & $21.5 \%$ & \\
\hline \multicolumn{6}{|l|}{ Year of study } \\
\hline Year 1 & $6.2 \%$ & $28.0 \%$ & $48.4 \%$ & $17.4 \%$ & \multirow{5}{*}{$<0.001$} \\
\hline Year 2 & $8.1 \%$ & $26.9 \%$ & $45.9 \%$ & $19.0 \%$ & \\
\hline Year 3 & $11.6 \%$ & $27.1 \%$ & $45.2 \%$ & $16.2 \%$ & \\
\hline Year 4 & $11.5 \%$ & $26.3 \%$ & $35.9 \%$ & $26.3 \%$ & \\
\hline Year 5 & $4.0 \%$ & $26.4 \%$ & $33.3 \%$ & $36.3 \%$ & \\
\hline \multicolumn{6}{|c|}{ Senior age or very young age increase the risk of nosocomial infection } \\
\hline & $\begin{array}{l}\text { Strongly } \\
\text { agree }\end{array}$ & Agree & Disagree & $\begin{array}{l}\text { Strongly } \\
\text { disagree }\end{array}$ & \\
\hline \multicolumn{6}{|l|}{ Field of study } \\
\hline Medical students & $10.1 \%$ & $48.1 \%$ & $33.7 \%$ & $8.0 \%$ & \multirow[t]{2}{*}{$<0.001$} \\
\hline Non-medical students & $15.3 \%$ & $50.1 \%$ & $26.7 \%$ & $7.9 \%$ & \\
\hline \multicolumn{6}{|l|}{ Gender } \\
\hline Male & $10.7 \%$ & $47.6 \%$ & $34.1 \%$ & $7.5 \%$ & \multirow[t]{2}{*}{0.474} \\
\hline Female & $11.5 \%$ & $49.0 \%$ & $31.3 \%$ & $8.2 \%$ & \\
\hline \multicolumn{6}{|l|}{ Year of study } \\
\hline Year 1 & $9.9 \%$ & $51.5 \%$ & $28.8 \%$ & $9.8 \%$ & \multirow{5}{*}{$<0.001$} \\
\hline Year 2 & $8.8 \%$ & $53.7 \%$ & $30.1 \%$ & $7.5 \%$ & \\
\hline Year 3 & $14.5 \%$ & $50.6 \%$ & $27.7 \%$ & $7.1 \%$ & \\
\hline Year 4 & $12.5 \%$ & $44.9 \%$ & $33.8 \%$ & $8.9 \%$ & \\
\hline Year 5 & $10.5 \%$ & $42.8 \%$ & $41.3 \%$ & $5.5 \%$ & \\
\hline
\end{tabular}

What is the average proportion of patients who suffer from nosocomial

\begin{tabular}{llllll} 
& & infection? & & & \\
& $0-10 \%$ & $11-20 \%$ & $>20 \%$ & Ido not know & \\
\hline Field of study & $19.7 \%$ & $34.3 \%$ & $11.9 \%$ & $34.1 \%$ & $<0.001$ \\
Medical students & $15.3 \%$ & $22.9 \%$ & $10.7 \%$ & $51.1 \%$ &
\end{tabular}

What is the average proportion of infected patients likely to die because of this

What is the average proportion of infected patients likely to die because of this

\begin{tabular}{llllll} 
& & & & & \\
& $0-2 \%$ & $3-5 \%$ & $>5 \%$ & Ido not know & \\
\hline Field of study & $25.5 \%$ & $28.8 \%$ & $8.2 \%$ & $37.5 \%$ & $<0.001$ \\
Medical students & $14.0 \%$ & $21.1 \%$ & $8.6 \%$ & $56.3 \%$ & \\
Non-medical students &
\end{tabular}

On average, by how many days would a hospital stay be prolonged because of a nosocomial infection?

$0-10$ days $11-20$ days $>20$ days

\begin{tabular}{|c|c|c|c|c|}
\hline & 10 days & $1-20 \mathrm{da}$ & >20 days & \\
\hline \multicolumn{5}{|l|}{ Field of study } \\
\hline Medical students & $51.2 \%$ & $38.1 \%$ & $10.8 \%$ & 0.013 \\
\hline Non-medical students & $47.3 \%$ & $37.7 \%$ & $15.0 \%$ & \\
\hline
\end{tabular}

The mean overall score (SD) was 2.045 (1.29) points. The average score among medical students $(2.113)$ was significantly higher than in non-medical students $(1.785, \mathrm{p}<0.001)$. The overall score did differ between male and female students (1.898 vs. 1.999, $p=0.048$ ). The score progressively increased with a year of study, and the maximum score of 2.218 was observed in year 5 medical students (Table 3).

Regardless of the students' field, many respondents showed a vague knowledge of the standard precaution concept in Kazakhstan (Table 4). Awareness of standard preventive measures increased with a year of study, but only a third of year 5 students were aware of standard prevention $(36.3 \%$ vs. $17.4 \%$ in year 1 students, $p<0.001)$. Most of students of all years of study identified age as a risk factor of $\mathrm{NI}$ (Table 4). Awareness of both average proportion of patients suffering from $\mathrm{NI}$ and mortality from $\mathrm{NI}$ was higher among medical vs. non-medical students $(\mathrm{p}<0.001)$

Awareness of the average proportion of patients who suffer and would die from $\mathrm{Nl}$ among medical students increased with a year of study. This could be related to available courses on infection control in individualized education plans. Most students responded that the patient hospital stay due to $\mathrm{NI}$ could be extended to 10 days (Table 5).

Among proposed reasons for not following the transmission precautions, lack of knowledge was cited as the most important barrier $(45.1 \%)$, followed by forgetfulness $(35.3 \%)$, lack of means (29.4\%), and lack of time (29.3\%). In non-medical students, compared with medical students, lack of knowledge (38.2\% vs. $47.0 \%, p<0.001)$ and forgetfulness $(29.3 \%$ vs. $37.0 \%, p=0.001)$ were considered less important (Table 6).

\section{Discussion}

Prior to our study, there were no other studies conducted in Kazakhstan on standard precautions for NIs and related topics. Our study contributes to the knowledge assessment of Karaganda Medical University students, and also evaluates the adequacy of their training. Our findings agree with some studies on the knowledge of medical students regarding precautionary measures $[9,12,18,25-35]$.

Our results show that general knowledge of standard precautions is unsatisfactory among the studied groups. This finding implies poor level of preparation from the very beginning of studying the topic at a university. The average score of knowledge in medical students was not much different from nonmedical students who did not have specialized courses on epidemiology and prevention of NIs in their curriculum. Marginally sufficient score was achieved only by students of years of study 3 and 5 , who had a course of epidemiology in their curriculum. The result suggests the inefficiency of the infection control curriculum at the medical university, hence appropriate interventions are needed to improve the situation.

The results of our research are similar to previous studies: they highlighted gaps in the training of medical students pointing at their low level of knowledge on NI. A third of medical students admitted lack of awareness of morbidity and mortality from NI. Interestingly, in many cases, students in our research claimed sufficient proficiency in the concepts of standard precautions, although the score of their knowledge on standard precautions was fairly low. Despite their own judgments on $\mathrm{NI}$ awareness, our 
questionnaires revealed a lack of knowledge on, and attention to, nosocomial infections.

Regarding such results, we suppose that one of their causes is an underestimation of the importance of standard precautions for Nls. As suggested by F. Brosio et al., more efforts should be made to enhance knowledge on NIs [12]. Special training in standard precautions, such as mentoring, good clinical practice modeling and computer-based training package would help improving students' knowledge and developing major attributes of professional behavior, identity, and values $[23,35,36]$.

Absence of the specific national plan on preventing NIs in Kazakhstan could be a possible explanation of limited knowledge on $\mathrm{NI}$ among the students. Their poor knowledge could be also explained by the lack of policies and/or guidelines for NIs in the field of infection control, both at the national and institutional levels. As this finding implies, policies on NI prevention are not aimed at developing much better knowledge on standard precautions among students.

Table 5. Analysis of responses about the epidemiological situation with nosocomial infection in Kazakhstan

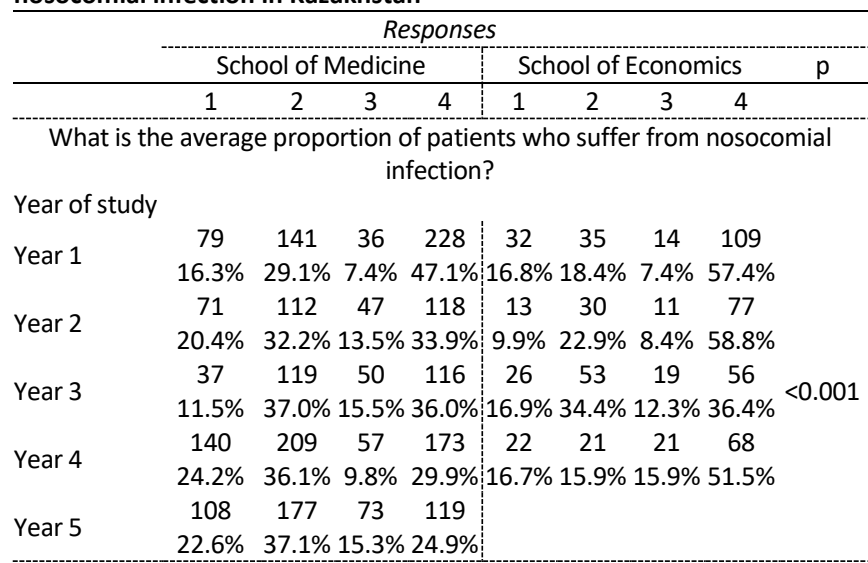

What is the average proportion of infected patients likely to die because of this infection?

Year of study

\begin{tabular}{lllll|llll} 
Year 1 & 105 & 121 & 26 & 232 & 28 & 37 & 10 & 115
\end{tabular}

$21.7 \% \quad 25 \% \quad 5.4 \% \quad 47.9 \%$ : $14.7 \%$ 19.5\% $5.3 \% \quad 60.5 \%$

$22.1 \% \quad 31.3 \% 10.1 \% 36.5 \% 12.2 \% 23.7 \% \quad 9.9 \% 54.2 \%$ \begin{tabular}{ccccc|cccc} 
Year 3 & 66 & 99 & 24 & 133 & 24 & 35 & 18 & 77 \\
& $20.5 \%$ & $30.7 \%$ & $7.5 \%$ & $41.3 \%$ & $15.6 \%$ & $22.7 \%$ & $11.7 \%$ & $50.0 \%$
\end{tabular}$<.001$

$\begin{array}{ccccc:cccc} & 155 & 167 & 60 & 197 & 17 & 25 & 11 & 79 \\ \text { Year } 4 & 26.8 \% & 28.8 \% & 10.4 \% & 34.0 \% & 12 \% & 18.9 \% & 8.3 \% & 59.8 \%\end{array}$ $\begin{array}{llll}160 & 140 & 37 & 140\end{array}$

Year $5 \quad 33.5 \% \quad 29.4 \% 7.8 \% 29.4 \%$

On average, by how many days would a hospital stay be prolonged because of a nosocomial infection?

Year of study

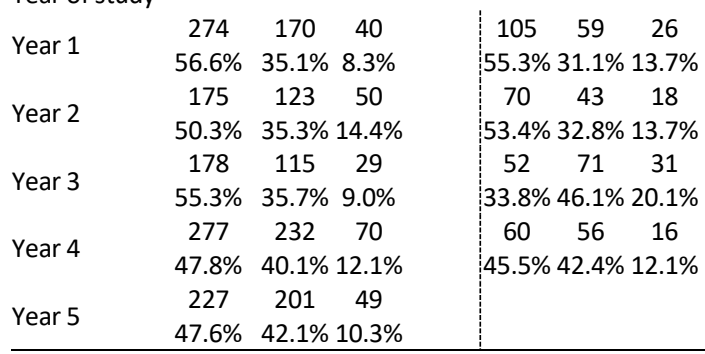

$<0.001$
Table 6. Analysis of responses regarding the perceived barriers to compliance with the standard precautions' guidelines

\begin{tabular}{|c|c|c|c|c|c|}
\hline $\begin{array}{l}\text { Perceived } \\
\text { barriers }\end{array}$ & & $\begin{array}{c}\text { Not } \\
\text { important, \% }\end{array}$ & Important, \% & $\begin{array}{c}\text { Very } \\
\text { important, } \%\end{array}$ & $p$ \\
\hline \multirow[t]{13}{*}{$\begin{array}{l}\text { Lack of } \\
\text { knowledge }\end{array}$} & & 8.7 & 46.2 & 45.1 & \\
\hline & Field of study & & & & \\
\hline & Medical students & 6.8 & 46.2 & 47.0 & $<0.001$ \\
\hline & Non-medical st. & 15.8 & 46.0 & 38.2 & \\
\hline & Gender & & & & \\
\hline & Male & 10.9 & 43.1 & 46.0 & 0.005 \\
\hline & Female & 7.7 & 47.7 & 44.7 & \\
\hline & Year of study & & & & \\
\hline & Year 1 & 11.9 & 38.3 & 49.9 & \\
\hline & Year 2 & 8.8 & 43.6 & 47.6 & $<0001$ \\
\hline & Year 3 & 8.8 & 55.3 & 35.9 & $<0.001$ \\
\hline & Year 4 & 8.7 & 44.2 & 47.1 & \\
\hline & Year 5 & 4.2 & 53.9 & 41.9 & \\
\hline \multirow[t]{13}{*}{ Forgetfulness } & & 9.1 & 55.6 & 35.3 & \\
\hline & Field of study & & & & \\
\hline & Medical students & 8.6 & 54.4 & 37.0 & 0.001 \\
\hline & Non-medical st. & 10.9 & 59.8 & 29.3 & \\
\hline & Gender & & & & \\
\hline & Male & 11.6 & 54.6 & 33.8 & 0.005 \\
\hline & Female & 7.9 & 56.1 & 36.0 & \\
\hline & Year of study & & & & \\
\hline & Year 1 & 9.5 & 50.1 & 40.4 & \\
\hline & Year 2 & 12.3 & 56.4 & 31.3 & \\
\hline & Year 3 & 8.8 & 66.2 & 25.0 & $<0.001$ \\
\hline & Year 4 & 9.1 & 51.6 & 39.2 & \\
\hline & Year 5 & 5.5 & 57.9 & 36.7 & \\
\hline \multirow[t]{13}{*}{ Lack of means } & & 19.8 & 50.8 & 29.4 & \\
\hline & Field of study & & & & \\
\hline & Medical students & 20.6 & 50.2 & 29.2 & 0.162 \\
\hline & Non-medical st. & 17.1 & 52.9 & 30.0 & \\
\hline & Gender & & & & \\
\hline & Male & 21.6 & 48.5 & 30.0 & 0.169 \\
\hline & Female & 19.0 & 51.9 & 29.1 & \\
\hline & Year of study & & & & \\
\hline & Year 1 & 26.1 & 48.7 & 25.2 & \\
\hline & Year 2 & 23.2 & 52.4 & 24.4 & $<0001$ \\
\hline & Year 3 & 13.9 & 57.1 & 29.0 & $<0.001$ \\
\hline & Year 4 & 18.0 & 46.4 & 35.6 & \\
\hline & Year 5 & 16.4 & 52.2 & 31.4 & \\
\hline \multirow[t]{13}{*}{ Lack of time } & & 15.4 & 55.3 & 29.3 & \\
\hline & Field of study & & & & \\
\hline & Medical students & 15.8 & 55.8 & 28.3 & 0.083 \\
\hline & Non-medical st. & 13.8 & 53.4 & 32.8 & \\
\hline & Gender & & & & \\
\hline & Male & 15.9 & 54.4 & 29.8 & 0.779 \\
\hline & Female & 15.2 & 55.8 & 29.1 & \\
\hline & Year of study & & & & \\
\hline & Year 1 & 15.1 & 53.3 & 31.6 & \\
\hline & Year 2 & 22.1 & 53.0 & 24.8 & \\
\hline & Year 3 & 13.2 & 64.7 & 22.1 & 0.001 \\
\hline & Year 4 & 15.6 & 51.8 & 32.6 & \\
\hline & Year 5 & 10.9 & 56.4 & 32.7 & \\
\hline
\end{tabular}

Non-medical students in our study served a background to $\mathrm{NI}$ knowledge of medical students. However, regardless of the field of study, both groups displayed unsatisfactory awareness of NI. This result points out that current professional training of medical students does not succeed in augmenting their awareness of NIs. Moreover, training of medical students on NIs does not 
significantly differ from non-medical students. This result is quite alarming finding for the national education and healthcare systems. Educational programs on infection control should be revised for patient safety as well as for improvement of student knowledge. According to A.A. Ibrahim et al., a medical education program should be started at the college level before clinical practice starts, emphasizing the importance of infection control guidelines [9].

One of the limitations was low reliability of the knowledge scale that could have weakened the expected associations.

\section{Conclusion}

Our study revealed the inadequate knowledge and awareness of the infection prevention and control guidelines among medical students. Their responses did not suggest high level of knowledge in the field of preventing Nls, compared with non-medical students.

Only through a proper training of medical students, there is a possibility of changing the situation with the prevalence of NIs in Kazakhstan for better. As a recommendation for improvement of the hospital patient safety, this study proposes an introduction of infection control educational programs at medical universities of Kazakhstan. Additionally, there is a need to come up with novel policies targeting major issues of infection prevention at the national and local levels. Hence, the Ministry of Healthcare, hospitals, medical universities and other interested parties should enhance the knowledge and practices of the standard precautions for nosocomial infections.

\section{Ethical approval}

Permission for this study was obtained from the Ethics Committee of Karaganda Medical University. A cover letter explaining the purpose of the study and requesting participation was attached to each questionnaire. Signed written informed consent form was received from each participant. Confidentiality and anonymity of the respondents were maintained ensured by encrypting names with codes. The study was carried out according to the guidelines of the Declaration of Helsinki.

\section{Funding}

The authors state that there was no external funding for this study.

\section{Acknowledgments}

We would like to express our sincere gratitude to the students who participated in our study.

\section{Conflict of interest}

The authors declare that they have no conflicts of interest.

\section{References}

1. Revelas A. Healthcare - associated infections: A public health problem. Niger Med J 2012; 53(2): 59-64. https://doi.org/10.4103/03001652.103543

2. Stone PW, Braccia D, Larson E. Systematic review of economic analyses of health care-associated infections. Am J Infect Control 2005; 33(9): 501-509. https://doi.org/10.1016/j.ajic.2005.04.246.

3. Marcel JP, Alfa M, Baquero F, Etienne J, Goossens H, Harbarth S, et al. Healthcare associated infections: Think globally, act locally. Clin Microbiol Infect 2008; 14(10): 895-907. https://doi.org/10.1111/j.1469-0691.2008.02074.x.
4. World Health Organization (WHO). Report on the burden of endemic health care-associated infection worldwide. Geneva, Switzerland: WHO Document Production Services. 2011; 34 p. http://apps.who.int/iris/bitstream/10665/80135/1/9789241501507_e ng.pdf.

5. World Health Organization (WHO). Guidelines on Hand Hygiene in Health Care: First Global Patient Safety Challenge Clean Care Is Safer Care. Geneva, Switzerland: WHO. 2009; 262 p. https://apps.who.int/iris/bitstream/handle/10665/44102/9789241597 906 eng.pdf

6. Garner JS. Guideline for isolation precautions in hospitals. The Hospital Infection Control Practices Advisory Committee. Infect Control Hosp Epidemiol 1996; 17(1): 53-80. https://doi.org/10.1086/647190.

7. Beltrami EM, Williams IT, Shapiro CN, Chamberland ME. Risk and management of blood-borne infections in health care workers. Clin Microbiol Rev 2000; 13(3): 385-407. https://doi.org/10.1128/cmr.13.3.385.

8. Ayub A, Goyal A, Kotwal A, Kulkarni A, Kotwal A, Mahen A. Infection control practices in health care: Teaching and learning requirements of medical undergraduates. Med J Armed Forces India 2013; 69(2): 107112. https://doi.org/10.1016/j.mjafi.2012.07.021.

9. Ibrahim AA, Elshafie SS. Knowledge, awareness, and attitude regarding infection prevention and control among medical students: A call for educational intervention. Adv Med Educ Pract 2016; 7: 505-510. https://doi.org/10.2147/amep.s109830.

10. Bello Al, Asiedu EN, Adegoke BO, Quartey JN, Appiah-Kubi KO, OwusuAnsah B. Nosocomial Infections: Knowledge and source of information among clinical health care students in Ghana. Int J Gen Med 2011; 4: 571-574. https://doi.org/10.2147/ijgm.s16720.

11. Zeigheimat F, Ebadi A, Rahmati-Najarkolaei F, Ghadamgahi F. An investigation into the effect of health belief model-based education on healthcare behaviors of nursing staff in controlling nosocomial infections. J Edu Health Promot 2013; 5: 23. https://doi.org/10.4103/2277-9531.184549.

12. Brosio F, Kuhdari P, Stefanati A, Sulcaj N, Lupi S, Guidi E, et al. Knowledge and behavior of nursing students on the prevention of healthcare associated infections. J Prev Med Hyg 2017; 58(2): E99E104. https://pubmed.ncbi.nlm.nih.gov/28900349

13. Sax H, Perneger T, Hugonnet S, Herrautl P, Chraïti MN, Pittet D. Knowledge of standard and isolation precautions in a large teaching hospital. Infect Control Hosp Epidemiol 2005; 26(3): 298-304. https://doi.org/10.1086/502543.

14. Tavolacci MP, Ladner J, Bailly L, Merle V, Pitrou I, Czernichow P. Prevention of nosocomial infection and standard precautions: Knowledge and source of information among healthcare students. Infect Control Hosp Epidemiol 2008; 29(7): 642-647. https://doi.org/10.1086/588683.

15. Monsalve Arteaga LC, Martínez Balzano CD, Carvajal De Carvajal AC. Medical students' knowledge and attitudes towards standard precautions. J Hosp Infect 2007; 65(4): 371-372. https://doi.org/10.1016/j.jhin.2006.11.009.

16. Mitchell BG, Say R, Wells A, Wilson F, Cloete L, Matheson L. Australian graduating nurses' knowledge, intentions and beliefs on infection prevention and control: A cross-sectional study. BMC Nurs 2014; 13(1): 43. https://doi.org/10.1186/s12912-014-0043-9.

17. Bergamini M, Cucchi A, Stefanati A, Cavallaro A, Gabutti G. Knowledge of preventive measures against occupational risks and spread of healthcare-associated infections among nursing students. An epidemiological prevalence study from Ferrara, Italy. J Prev Med Hyg 2009; 50(2): 96-101. https://pubmed.ncbi.nlm.nih.gov/20099439.

18. D’Alessandro D, Agodi A, Auxilia F, Brusaferro S, Calligaris L, Ferrante $M$, et al. Prevention of healthcare associated infections: Medical and nursing students' knowledge in Italy. Nurse Educ Today 2014; 34(2): 191-195. https://doi.org/10.1016/j.nedt.2013.05.005. 
19. Tawalbeh LI, Al-Rawajfah OM, Habiballah L. The effect of infection control course on nursing students' knowledge of and compliance with universal precautions: A quasi-experimental study. Dimens Crit Care Nurs 2019; 38(3): 137-145. https://doi.org/10.1097/dcc.0000000000000352.

20. Hassan ZM. Improving knowledge and compliance with infection control Standard Precautions among undergraduate nursing students in Jordan. Am J Infect Control 2018; 46(3): 297-302. https://doi.org/10.1016/i.ajic.2017.09.010.

21. Sharif F, Khan A, Samad MA, Hamid A, Aijaz A, Asad I, et al. Knowledge, attitude, and practices regarding infection control measures among medical students. J Pak Med Assoc 2018; 68(7): 1065-1069. https://pubmed.ncbi.nlm.nih.gov/30317303.

22. Khubrani A, Albesher M, Alkahtani A, Alamri F, Alshmrani M, Masuadi E. Knowledge and information sources on standard precautions and infection control of health sciences students at King Saud bin Abdulaziz University for Health Sciences, Saudi Arabia, Riyadh. J Infect Public Health 2018; 11(4): 546-549. https://doi.org/10.1016/i.jiph.2017.10.013.

23. Rahiman F, Chikte U, Hughes GD. Nursing students' knowledge, attitude and practices of infection prevention and control guidelines at a tertiary institution in the Western Cape: A cross sectional study. Nurse Educ Today 2018; 20-25. https://doi.org/10.1016/i.nedt.2018.06.021.

24. Rutjes AW, Reitsma JB, Vandenbroucke JP, Glas AS, Bossuyt PM. Casecontrol and two-gate designs in diagnostic accuracy studies. Clin Chem 2005; 51(8): 1335-1341. https://doi.org/10.1373/clinchem.2005.048595.

25. Mehta Y, Gupta A, Todi S, Myatra S, Samaddar DP, Patil V, et al. Guidelines for prevention of hospital acquired infections. Indian J Crit Care Med 2014; 18(3): 149-163. https://doi.org/10.4103/0972$\underline{5229.128705}$

26. Siegel JD, Rhinehart E, Jackson M, Chiarello L, Healthcare Infection Control Practices Advisory Committee. Guideline for isolation precautions: Preventing transmission of infectious agents in healthcare settings. Centers for Disease Control and Prevention. 2007; 206 p. https://www.cdc.gov/infectioncontrol/guidelines/isolation/index.html.

27. Bartholomew D, Steele F, Galbraith J, Moustaki I. Analysis of Multivariate Social Science Data. 2nd Ed. New York: Chapman and Hall/CRC, 2008; 384 p. https://doi.org/10.1201/b15114.

28. Yazie TD, Sharew GB, Abebe W. Knowledge, attitude, and practice of healthcare professionals regarding infection prevention at Gondar University referral hospital, northwest Ethiopia: A cross-sectional study. BMC Res Notes 2019; 12(1): 563. https://doi.org/10.1186/s13104-019-4605-5.

29. Ogoina D, Pondei K, Adetunji B, Chima G, Isichei C, Gidado S. Knowledge, attitude and practice of standard precautions of infection control by hospital workers in two tertiary hospitals in Nigeria. $J$ Infect Prev 2015; 16(1): 16-22. https://doi.org/10.1177/1757177414558957.

30. Sarani H, Balouchi A, Masinaeinezhad N, Ebrahimitabas E. Knowledge, attitude and practice of nurses about standard precautions for hospital-acquired infection in teaching hospitals affiliated to Zabol University of Medical Sciences (2014). Glob J Health Sci 2015; 8(3): 193-198. https://doi.org/10.5539/gjhs.v8n3p193.

31. Goyal M, Chaudhry D. Impact of educational and training programs on knowledge of healthcare students regarding nosocomial infections, standard precautions and hand hygiene: A study at tertiary care hospital. Indian J Crit Care Med 2019; 23(5): 227-231. https://doi.org/10.5005/jp-journals-10071-23166.

32. Amin TT, Al Noaim KI, Bu Saad MA, Al Malhm TA, Al Mulhim AA, Al Awas MA. Standard precautions and infection control, medical students' knowledge and behavior at a Saudi university: The need for change. Glob J Health Sci 2013; 5(4): 114-125. https://doi.org/10.5539/gjhs.v5n4p114.

33. Majidipour P, Aryan A, Janatolmakan M, Khatony A. Knowledge and performance of nursing students of Kermanshah-Iran regarding the standards of nosocomial infections control: A cross-sectional study. BMC Res Notes 2019; 12(1): 485. https://doi.org/10.1186/s13104-0194533-4.

34. Feather A, Stone SP, Wessier A, Boursicot KA, Pratt C. 'Now please wash your hands': The handwashing behavior of final MBBS candidates. J Hosp Infect 2000; 45(1): 62-64. https://doi.org/10.1053/jhin.1999.0705.

35. Snow M, White GL Jr, Alder SC, Stanford JB. Mentor's hand hygiene practices influence student's hand hygiene rates. Am J Infect Contro 2006; 34(1): 18-24. https://doi.org/10.1016/j.ajic.2005.05.009.

36. Desai N, Philpott-Howard J, Wade J, Casewell M. Infection control training: Evaluation of a computer-assisted learning package. J Hosp Infect 2000; 44(3): 193-199. https://doi.org/10.1053/jhin.1999.0673.

\section{Authors:}

Elmira Kultanova - PhD student, Karaganda Medical University, Karaganda, Kazakhstan. https://orcid.org/0000-0002-6182-5933.

Milton Severo - PhD, Institute of Public Health; Department of Public Health, Forensic Sciences and Medical Education, School of Medicine, University of Porto, Porto, Portugal. https://orcid.org/0000-0002-57874871.

Anar Turmukhambetova - MD, PhD, Associate Professor, Vice-Chancellor, Karaganda Medical University, Karaganda, Kazakhstan. https://orcid.org/0000-0002-4668-3295. 
Appendix 1. Fulltext of questionnaire

\section{Dear Respondent!}

We would appreciate your participation in our study on knowledge of infection control by filling out this questionnaire. It would only take 10 minutes of your time.

Please, reply honestly and independently. The answers will be used in the cumulative form

1. Your gender $\square$ Female $\square$ Male

2. Date of birth:

3. Your field of study

4. Your year of study:

$\square$ Year 1

$\square$ Year 2

$\square$ Year 3

$\square$ Year 4

$\square$ Year 5

5. What is the most important vehicle of transmitting infectious agents in the hospital?

$\square$ Healthcare instruments

$\square$ Air

$\square$ Hands

$\square$ Food

6. What would be your first choice to reduce transmission of infectious agents most effectively?

$\square$ Mask

$\square$ Latex gloves

$\square$ Hand hygiene

$\square$ Apron

7. Do you know your country-specific concept of standard precautions (CDC, WHO)?

$\square$ Never heard about it

$\square$ I heard about it

$\square$ Vague knowledge

$\square$ l know it well

8. Does senior age or very young age increase the risk of a nosocomial infection?

$\square$ Strongly agree

$\square$ Agree

$\square$ Disagree

$\square$ Strongly disagree

9. What is the average proportion of patients who suffer from nosocomial infection?

$\square 0 \%-10 \%$

$\square 11 \%-20 \%$

$\square>20 \%$

$\square$ I do not know

10. What is the average proportion of infected patients likely to die because of this infection?

$\square 0 \%-2 \%$

$\square 3 \%-5 \%$

$\square>5 \%$

$\square$ I do not know

11. On average, by how many days would a hospital stay be prolonged because of a nosocomial infection?

$\square$ 0-10 days

$\square$ 11-20 days

$\square>20$ days

12. What are non-sterile gloves used for?

$\square$ To protect healthcare workers when having contact with intact skin of a patient

$\square$ To protect a patient against transmission of an infectious agent by hands

$\square$ To protect healthcare workers when having contact with blood or another body fluid

$\square$ To protect healthcare workers when a patient has symptomatic infection
13. Hand hygiene immediately before caring for a patient $\square$ Helps protecting healthcare workers

$\square$ Is useful to protect a patient

$\square$ Helps protecting the environment

$\square$ Is useful only for infected patients

14. Transmission prevention of infectious agents involves mainly:

$\square$ Isolating all infected patients

$\square$ Hospitalization of all patients in individual wards

$\square$ Following preventive measures in accordance with the risk degree of transmission

$\square$ Proper treatment of infections

15. Does accidental splashing of a patient's body fluid in a healthcare worker's eye represent a risk of systemic infection?

$\square$ Yes, but only if the patient has an identified infection

$\square$ No, healthcare workers have sufficient innate immune defense

$\square$ Yes, regardless of the type of splashing

$\square$ Not if the healthcare worker is vaccinated against hepatitis B

16. In everyday work, prevention guidelines are not always followed. What are your judgements about the following options? (Please reply regarding each option)

Lack of knowledge: $\square$ not important $\square$ important $\square$ very important

Forgetfulness: $\square$ not important $\square$ important $\square$ very important

Lack of means: $\square$ not important $\square$ important $\square$ very important

Lack of time: $\quad \square$ not important $\square$ important $\square$ very important

Thank you very much for your time! 